\title{
Ösztrogének és ösztrogénhatású anyagok a növénytermesztésben
}

\author{
${ }^{1 *}$ Gubó Eduard, ${ }^{1}$ SZAKÁL Pál, ${ }^{1,2}$ PLUTZER Judit \\ ${ }^{1}$ Széchenyi István Egyetem, Mezőgazdaság- és Élelmiszertudományi Kar, \\ Mosonmagyaróvár, ${ }^{2}$ Nemzeti Népegészségügyi Központ, Budapest \\ (Beérkezett: 2018.08.29.; Elfogadva: 2019.09.16.)
}

\section{Bevezetés}

Az állattenyésztésből származó istállótrágya az emberiség által régóta ismert és hasznosított értékes mezőgazdasági melléktermék, mely nemcsak a növények tápanyagszükségleteit elégíti ki, hanem pozitívan befolyásolja a talaj szerkezetét, humusztartalmát, víz- levegő- és hőgazdálkodását. A folyamatos ipari fejlődés mellett a mezőgazdaság is egyre korszerübbé és automatizáltabbá vált, az 1970-es évek elején megjelent az almozás nélküli állattartás, mely nagy mennyiségü hígtrágya keletkezését eredményezte. Termőföldre történő kijuttatásával viszonylag gyorsan hasznosítható tápanyagokat biztosíthatunk a növényi kultúrák számára. A hígtrágya szakszerü, ellenőrzött és környezetkímélő felhasználása tápanyaggazdálkodási és környezetvédelmi szempontból egyaránt fontos. A hígtrágya alkotóelemeinek - hasonlóan más szerves hulladékokhoz - elöször a növények számára hasznos, könnyen felvehető tápanyagokká kell alakulniuk. Kezelése és felhasználása a mezőgazdasági üzemekben elsősorban folyamatosan termelődő nagy mennyisége, és szakaszos felhasználási lehetősége miatt okoz gondot, ami miatt tárolási lehetőség biztosítása szükséges. A felhasználásra vonatkozólag (ellentétben az istállótrágyával) nem támaszkodhatunk a régmúlt hagyományaira, nem ismert pontosan, hogy az alkalmazott tárolási, hígtrágya előkezelési és kijuttatási módszerek hozzájárulnak-e a benne levő kémiai vegyületek megfelelő lebomlási folyamataihoz.

A globális iparosodás megindulása óta az emberi és állati hormonrendszert befolyásoló anyagok, főként az ösztrogénhatású vegyületek jelenléte a környezetben komoly aggodalmat váltott ki. A szteroid ösztrogének, köztük az ösztron (E1), az ösztradiol (E2) és az ösztriol (E3) által okozott szennyezés, problémát jelent a talajra, a növényekre, a vízforrásokra és a táplálékláncba jutva az emberekre nézve is. Ebben az összefoglaló tanulmányban bemutatjuk a legfontosabb hormonrendszert zavaró vegyületeket, és az ösztrogénhatású anyagokat. Felhívjuk a figyelmet az intenzív, modern mezőgazdaság potenciális kockázatára és áttekintjük, hogy ezek az anyagok hogyan hatnak a növényekre.

*Levelezö szerzö: GUBÓ EDUARD, Széchenyi István Egyetem, Mezőgazdaság- és Élelmiszertudományi Kar, 9200 Mosonmagyaróvár, Vár tér 2.

E-mail: gubo.eduard@gmail.com 


\section{A talaj és a talajszennyezés fogalma}

A földműveléssel és állattenyésztéssel foglalkozó ember rájött, hogy a talaj az egyik legfontosabb tényezője a sikeres gazdálkodásnak, ezért nagy figyelmet fordít rá. A talaj a növények termőhelyéül szolgál, mely a Föld legkülső, szilárd burkát képezi. Meghatározó tulajdonsága a termőképesség, képes a növényeket tápanyagokkal és vízzel ellátni. A mezőgazdaság termelőeszköze és a környezet része, mely elnyeli, tárolja vagy átalakítja a földfelszínre érkező energia és anyagáramlásokat. A talaj az egyik legfontosabb természeti erőforrás, amely az anyagok zavartalan körforgásában megújulni képes (STEFANOVITS,1992). VERMES és SIMON $(1995,1999)$ szerint minden olyan folyamatot, amely során a talaj fizikai, kémiai és biológiai tulajdonságai kedvezőtlen irányban megváltoznak, és az ökológiai funkciók károsodnak, talajszennyezésnek tekintünk. Leggyakrabban kémiai anyagok okozhatnak talajszennyeződést, a toxikus fémek és vegyületeik felhalmozódásával.

Ezek legnagyobb mértékben antropogén (emberi) eredetűek, melyek pontszerü vagy diffúz (nem pontszerü) szennyezést okoznak a talajban. Pontszerü antropogén talajszennyeződéshez soroljuk a szennyvizek, szennyvíziszapok, hígtrágyák, istállótrágyák, folyékony és szilárd hulladékok következtében kialakult minőségromlást. Diffúz antropogén szennyeződést okoznak a légszennyezésből eredő nedves és száraz kiülepedések, a mezőgazdaságban felhasznált vegyszerek (növényvédő szerek, mütrágyák). Az emberi tevékenység hatására a talajba kerülhetnek még kőolaj és kőolajszármazékok, szervetlen makroszennyezők, szerves mikroszennyezők, nehézfémek és radioaktív anyagok is (KÁDÁR, 1995; SiMON, 1999; VERMES, 1995).

\section{A hígtrágya és annak felhasználása}

A hígtrágya az almozás nélküli állattartás jellegzetes, folyékony halmazállapotú mellékterméke, amely állati bélsárból, vizeletből, elcsurgó ivó- és technológiai vízből, valamint kis mennyiségben egyéb hulladék anyagokból áll. Ennek a trágyaféleségnek a megjelenése hazánkban az 1970-es évek elejére tehetö, a nagyüzemi állattartó telepek létesítésével párhuzamosan (VERMES, 2005). A hígtrágyát az alkalmazott technológiák képesek különböző mértékben a szilárd és folyékony alkotórészeire elkülöníteni. A szilárd fázis kiszürhető, kiülepíthető, mely szikkadás után az almos trágyával hasonló módon kezelhető. A visszamaradt híg szuszpenzió nem azonos a trágyalével, mivel kevesebb tápanyagot tartalmaz. (CSÁVÁs et al., 1975).

Az istállótrágya és hígtrágya a tápanyag szolgáltató képességükön keresztül tudnak hatást gyakorolni a talajra. Jótékony hatásai túlnőnek a közvetlen tápanyagellátáson. A gyakorlati tapasztalatok azt mutatják, hogy a nagy mütrágyaadagokat használó növénytermesztésben is nélkülözhetetlen az istállótrágyázás, ugyanis a szerves anyaggal kijuttatott széntartalom jelentős energiaforrást biztosít a talajokban lejátszódó mikrobiális folyamatok számára. 
Rendszeres trágyázással javítani tudjuk talajaink szerkezetét, emellett pedig kedvezően hatunk a talaj három fázisú (víz, levegő, hö) rendszerének müködésére. A fenntartható növénytermesztés alappillérének tekintjük a hatékony és jó minőségben elvégzett szervestrágyázást (KALOCSAI et al., 2007).

A hígtrágya kijuttatásáról és szakszerü felhasználásáról a 2007. évi CXXIX törvény a termőföld védelméröl, az 59/2008. (IV.29) FVM rendelet, továbbá a 41/1997. (V.28) FM rendelet részletesen rendelkezik, miszerint hígtrágya csak talajtani szakvéleményre alapozott talajvédelmi hatósági engedély birtokában juttatható ki mezőgazdasági területre. A talajtani szakvélemény alapja a talaj, a mezőgazdasági terület földrajzi viszonyainak alapos áttekintése és a hígtrágya analitikai elemzése (tápanyagtartalom, összes oldott sótartalom), de a potenciális szennyező anyagok például hormontartalom, ösztrogének vizsgálatát nem tartalmazza.

\section{Környezeti ösztrogének}

A bennünket körülvevő környezetben több ezer mesterséges és természetes eredetű vegyület van, melyek az élő szervezetekre különböző hatást fejthetnek ki. Vannak olyan lipidoldékony anyagok, melyek a természetes hormonok analógjaként müködnek, ezáltal megzavarhatják és felboríthatják az endokrin rendszer müködését és negatívan hathatnak létfontosságú élettani folyamatokra, mint például a szaporodásra, növekedésre, egyedfejlődésre (KAVLOCK et al., 1996; ANKLEY et al., 1997). Képesek megváltoztatni a hormonok bioszintézisét, tárolását, felszabadulását, szállítását (MCLACHLAN et al., 2006). A környezeti ösztrogének kifejezés kiterjed a növényi eredetü ösztrogénekre (fitoösztrogének), és az antropogén ösztrogénekre (xenoösztrogének). Mindkét csoport megtalálható a természetben, de éles különbség van az emberekre és a vadvilágra gyakorolt hatásukban. A xenoösztrogének a legújabb korban kerültek a környezetbe, a fitoösztrogének az állatfajok evolúciója során, beleértve saját magunkat is, mindvégig jelen voltak a Föld bioszférájában, tehát környezetünk szerves részei. Azon környezeti anyagokat, melyek a szervezetbe jutó dózisban beavatkoznak a szervezet hormon bioszintézisébe, anyagcseréjébe vagy müködésébe úgy, hogy megváltozik annak a normális homeosztázist fenntartó szabályozása, illetve a normális reprodukció biztosítása feletti kontrollja, összefoglaló néven endokrin rendszert megzavaró vegyületeknek (Endocrine Disrupting Compound-EDC) nevezzük. Az EDC-k szerkezetileg nagyon sokszínüek, több kémiai vegyületcsoportba tartozhatnak, ami megnehezíti a szisztematikus kutatásokat és vizsgálatokat. Sok EDC egy vagy több aromás gyürüt és klórt is tartalmaz (BYRNE et al., 2009).

A mezőgazdaság és az ipar felgyorsult fejlödésével egyre több EDC kerül a környezetünkbe. Mennyiségileg ezek az anyagok a szubtoxikus koncentráció alattiak, azonban a vegyületek többsége stabil, nehezen bomlanak le, képesek az élő szervezetekben felhalmozódni, más anyagokkal kapcsolatba lépni és akár új vegyületek formájában hatásukat kifejteni. Az élölények legtöbbször hosszabb ideig érintkeznek ezekkel az anyagokkal, így alacsony koncentráció is elegendő ahhoz, 
hogy biológiai hatást váltson ki az élő szervezeteknél (GAGNON et al.,1995; MCMASTER et al.,1991). Hormonhatású anyagok legtöbbször táplálékon keresztül, szennyezett vízzel, levegővel, talajjal történő érintkezéssel juthatnak a szervezetbe (DUDUTZ et al., 2009).

\section{Fitoösztrogének}

A fitoösztrogének olyan növényi eredetü vegyületek, melyek képesek kötődni az ösztrogén receptorokhoz és ösztrogénszerủ vagy anti-ösztrogén hatást fejtenek ki. Az emberi fitoösztrogén expozíció folyamatosan jelen van az életünkben, legnagyobb részt a hüvelyesekkel, magvakkal és a teljes kiőrlésủ gabonák fogyasztásával kerülnek a szervezetünkbe. A fitoösztrogének a xenoösztrogénekkel ellentétben nem bioakkumulálódnak (raktározódnak) a szervezetben, mivel viszonylag gyorsan lebomlanak, kiválasztódnak (WATANABE et al., 1998; MANACH és DONOVAN, 2004).

A fitoösztrogének lehetnek kromén származékok, flavonoidok, izoflavonoidok, izokumarinok, kalkonok, kumesztánok, stilbének, lignánok, ginzenozidok, tetrahidrofurandiolok, fahéjsav származékok, 2- arilbenzofuránok és számos egyéb fenolos vegyület. Az emberek legnagyobb mennyiségben az izoflavonoidok (föleg hüvelyesek) és a lignánok (majdnem minden növényben található) csoportjába tartozó fitoösztrogéneket fogyasztják (ADLERCREUTZ és MAZUR, 1997; REINLI és BLOCK, 1996). Bár kisebb mennyiségben, de a napraforgó, mogyoró, szezámmag, tök, kávé és a tea is tartalmaz lignánokat (MAZUR és ADLERCREUTZ, 1998).

Fontos tudni, hogy a fitoösztrogének hatásfoka többnyire kisebb, mint a mesterséges ösztrogéneké és a petefészek ösztrogének által szabályozott génjeinek spektrumát nem feltétlenül aktiválják. A xenoösztrogének ellenben megzavarhatják a természetes hormonháztartást: a természetes ösztrogén receptorokat lefoglalhatják, és ösztrogén dominanciát alakíthatnak ki (ISE et al., 2005; NACIFF et al., 2002).

A fitoösztrogénben gazdag ételek több hasznos komponenst is tartalmaznak, melyek hozzájárulnak a szervezet egészséges müködéséhez. A lenmag például élelmi rostokban, E-vitaminban gazdag és linolénsavat (esszenciális zsírsav) tartalmaz. A tea és a bogyós termések epikatekin-gallátokat, antociánokat tartalmaznak, melyeknek antioxidáns hatásuk van (HwANG et al., 2000; AMBRA et al., 2006; PETERSON, 1995). A fitoösztrogének optimális mennyisége tehát kedvező tulajdonságokkal hat az élő szervezetekre, ugyanis javíthatja a keringési rendszer müködését, és segíthet a daganatos megbetegedések kialakulásának megelőzésében (SIOW et al.,2007; RAMOS,2007).

Fontos megemlíteni, hogy a fitoösztrogéneknek számos negatív hatását is megfigyelték a természetben a vadon élő és tenyésztett állatok körében. A nagy mennyiségben fitoösztrogént tartalmazó növények elfogyasztása ugyanis kedvezötlen hatással van az élőlényekre. A fitoösztrogének, melyek szerkezetileg és funkcionálisan hasonlítanak a 17ß-E2-hoz, fejlődési rendellenességeket okozhatnak háziállatoknál. Egyes növények elegendő koncentrációban tartalmaznak fitoösztrogént, hogy reprodukciós változásokat okozzanak a háziállatokban. Például 
a lóhere, mezőn legeltetett juhoknál a növény magas fitoösztrogén szintje miatt meddőséget okozhat, melyet lóhere-betegségnek is neveznek (HоTCHKISs et al., 2008).

\section{Xenoösztrogének}

A megnövekedett ipari és mezőgazdasági fejlődés a II. világháború után új szintetikus szennyezőanyagokat hozott magával. A széles körben elterjedt peszticidek, müanyag-lágyító szerek, tisztítószerek, kozmetikumok, festékek a környezetünket szennyező anyagokká váltak, melyek befolyással lehetnek az endokrin rendszer funkcióira. Felismerték, hogy több gyógyszerként használt vegyület, mint például a dietilstilbösztrol (DES) káros hatással lehet az emberi egészségre. A vegyiparból kikerülő xenoösztrogének a környezetszennyezést követően kerülhetnek táplálékainkba (GUISTI et al., 1995; MCLACHLAN, 2001). Említésre méltó az állattenyésztésben használt rengeteg gyógyszer és ivarzást indukáló hormonhatású készítmény, melyek környezetünkbe kerülve szintén káros hatásúak lehetnek.

A xenoösztrogének kémiai szerkezetükben nagy heterogenitást mutatnak és különböznek a fitoösztrogénektöl. Mindenütt jelenlevő (ubiquiter) vegyületek, megtalálhatók a talajban, vízben, levegőben. Ellenállnak a kémiai és biológiai degradációnak, felezési idejük több évtized is lehet, ezért hosszú ideig jelen vannak a környezetben, felhalmozódhatnak a táplálékláncban és mivel az ember nem képes kiválasztani, sem lebontani, folyamatos veszélyt jelentenek. Idetartoznak olyan organoklorin vegyületek is, melyek a levegö porszemcséihez tapadva eljutnak iparilag érintetlen területekre is (FISHER, 1999).

Xenoösztrogének közé tartoznak bizonyos növényvédőszerek, mint például a diklór-difenil-triklóretán (DDT), a hexaklór-ciklohexán (HCH) (SHEKHAR et al., 1997), metoxiklór, endoszulfán, lindán, toxafén (VAN DER LINDEN et al., 2008)., müanyaglágyítók, mint a biszfenol A (BPA), ftalátok, felületaktív anyagok és degradációs termékeik, alkilfenolok, tartósítószerek, mint a parabének (NIMROD et al., 1996; GoMEZ et al., 2005).

A Perzisztens organikus pollutáns (POP) vegyületek stabil, erősen lipofil, ubiquiter szennyezők, melyek feldúsulnak a táplálékláncban, a zsírsejtekben raktározódnak és széles toxikológiai spektrummal rendelkeznek. Képesek átjutni a placentán és az anyatejjel kiválasztódnak (SOHÁR et al., 2003). Szerkezetüket tekintve polihalogénezett aromás szénhidrogének, melyek három fő csoportba sorolhatók. A csoportok két aromás gyürüt tartalmaznak, összekapcsolódásukban térnek el és változó számú és helyzetủ klór és bróm szubsztituenssel rendelkeznek. A figyelem középpontjában a poliklórozott bifenilek (PCB), poliklórozott dibenzodioxinok (PCDD) és poliklórozott dibenzofuránok (PCDF) vannak. Míg a PCB-ket ipari felhasználásra állítják elő szigetelőanyagokhoz, lágyítószerekhez, addig a PCDD/F-ek nem kívánatos ipari melléktermékek, melyek a vas és acélgyártás, hulladékégetés és klórtartalmú szerves vegyületek gyártása, papírfehérítés közben keletkeznek (RAPPE, 1994). Több tanulmány is foglalkozik a POP vegyületek EDC hatásaival. A POP vegyületek élettani szempontból létfontosságú funkciókra lehetnek hatással, negatívan befolyásolhatják a reprodukciós rendszer müködését 
(BUCK et al., 1997), csökkenthetik az immunrendszer normális müködését (WEISGLAS-KUPERUS et al., 2000), és számos daganatos megbetegedés forrásai lehetnek (SCHECTER és OLSON 1997). Ezek ismeretében az 1970-es évektöl kezdődően több ország is tilalmat vezetett be a POP vegyületek használatával kapcsolatban, például az alábbi növényvédőszerek használatára vonatkozólag: aldrin, dieldrin, DDT, heptaklór, toxafén.

A természetes és szintetikus ösztrogének és bomlástermékei

$\mathrm{Az}$ ösztrogének biológiailag aktív hormonok, amelyek koleszterinből származnak és a mellékvesekéregben, a herékben, a petefészekben és a placentában szabadulnak fel. A szteroid ösztrogéneket természetes vagy szintetikus hormonként lehet osztályozni, melyet az 1. ábra szemléltet.

1. ábra

A természetes és szintetikus ösztrogének kémiai struktúrája

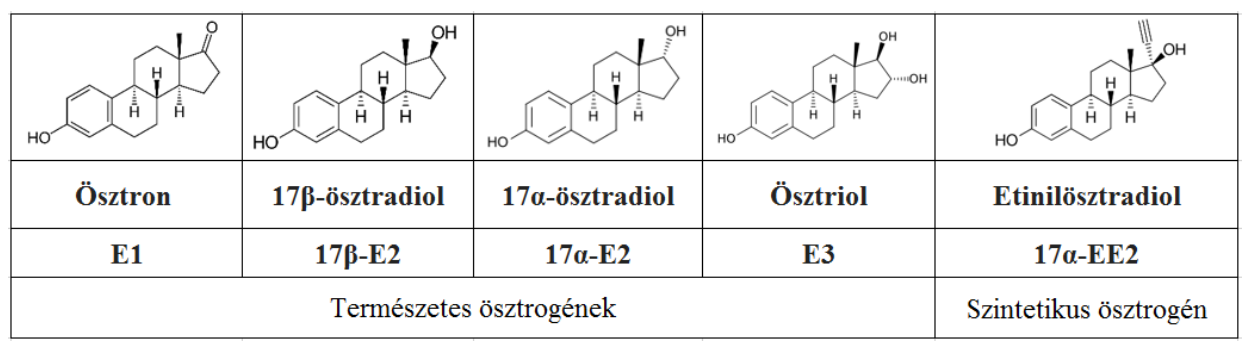

A világ több mint 7 milliárd főből álló lakossága körülbelül $30000 \mathrm{~kg}^{-1}{ }^{-1}$ természetes szteroid ösztrogént (E1, E2 és E3) és további $700 \mathrm{~kg}^{-1}{ }^{-1}$ szintetikus ösztrogént (EE2) kizárólag fogamzásgátlók által juttat a természetbe. Azonban az állattartásból származó ösztrogének jóval nagyobb mennyiséget tesznek ki. Például az Egyesült Államok és az Európai Unió, állatállományának éves ösztrogén kibocsátása, $83000 \mathrm{~kg}$ év $^{-1}$, az emberi kibocsátás több mint kétszerese (SHRESTHA et al., 2012). A vegyületek ösztrogén potenciálját legtöbbször a 17ß-ösztradiol referencia vegyülethez viszonyított relatív potenciálként fejezik ki. Meghatározó szerepe van a vegyületek minőségének, ugyanis az egyes ösztrogénhatású vegyületek különbözö hatással lehetnek a receptorokra. COLDHAM et al (1997) kutatásából tudjuk, hogy a 17ß-E2 (100\%) ösztrogén potenciáljához képest, a következőképpen alakul az EDC vegyületek receptor affinitása: 17 $\alpha$-EE2 $(88,8 \%)$, E1 (9,6\%), 17 $\alpha$-E2 (5,25\%), E3 (0,63\%), BPA (0,005\%).

WEI és munkatársai (2011) Észak-Kínai tejelő és hízó szarvasmarha telepen vizsgálták a trágyában előforduló ösztrogéneket. Megállapították, hogy a négy természetes ösztrogénből három megtalálható volt 17 tejelő telep trágyájában. Egyik telepen sem mutattak ki E3-at, viszont E1 a legmagasabb koncentrációban volt az összes tejelő telepen. $17 \alpha$ E2 és $17 \beta$ E2 a minták $70 \%$-ában kimutatható volt. A $17 \alpha$ E2, $17 \beta$ E2, és E1 átlagosan 194,6 $\mu \mathrm{g} \mathrm{kg}^{-1}, 104,4 \mu \mathrm{g} \mathrm{kg}^{-1}, 262,2 \mu \mathrm{g} \mathrm{kg}^{-1}$ mennyiségben fordultak elö a mintákban (WEI et al.,2011). 
A hízó marhák székletéből is kimutatható volt a $17 \alpha$ E2, 17 $\beta$ E2, és E1. A $17 \alpha$ E2 esetében a mennyisége $0 \mu \mathrm{g} \mathrm{kg}^{-1}$-tól egészen $260 \mu \mathrm{g} \mathrm{kg}^{-1}$-ig, a $17 \beta$ E2-nél szintén a $0 \mu \mathrm{g} \mathrm{kg}^{-1}$-tól 242,5 $\mu \mathrm{g} \mathrm{kg}^{-1}$-ig és az E1 pedig 103,1-507,5 $\mu \mathrm{g} \mathrm{kg}^{-1}$-ig terjedt. Átlagértékenként tehát: $104,5 \mu \mathrm{g} \mathrm{kg}^{-1}, 67,7 \mu \mathrm{g} \mathrm{kg}^{-1}$ és $216,4 \mu \mathrm{g} \mathrm{kg}^{-1}$. Az E3 nem volt kimutatható a vizsgált mintákban (ZHENG et al., 2008; HUTCHINS et al., 2007). A $17 \alpha \mathrm{E} 2,17 \beta \mathrm{E} 2$, és E1 átlagos koncentrációja a tejelö szarvasmarha székletében $86,3 \%, 54,2 \%$ és $21,2 \%$-kal volt magasabb, mint a hízó marha székletében (ZHENG et al.,2008).

A három ösztrogén koncentrációjának viszonylag nagy eltérése azt mutatja, hogy a szarvasmarha életkora, neme, szaporodási ciklusa, vemhességi stádiuma jelentős mennyiségbeli különbséget okozhat a trágyában található ösztrogének mennyiségében. HANSELMAN et al. (2003) a tanulmányukban leírják, hogy egy $1000 \mathrm{~kg}$ tömegü, nem vemhes vagy 80 nap alatti vemhes szarvasmarha 300-600 $\mu \mathrm{g}$ nap ${ }^{-1}$, míg egy $1000 \mathrm{~kg}$-os 80 nap feletti vemhes szarvasmarha $1500-11400$ $\mu \mathrm{g}$ nap $^{-1}$ ösztrogént választ ki.

JOHNSON et al. (2006) becslése szerint egy tejelö tehén átlagosan $384 \mathrm{mg}$ 17ß-ösztradiolt (E2) juttat naponta a környezetébe csupán a vizelettel és a széklettel, míg egy vemhes koca 700-17 000 mg ösztront (E1) üríthet a vizelettel napi szinten.

Az ösztrogének bomlási ideje elsősorban a degradációs körülmények mértékétől függ. Nyilvánvaló, hogy minél hosszabb a szennyezőanyag bomlási ideje, annál tartósabb lesz a környezetben. $\mathrm{Az}$ emberekben és állatokban kiválasztódó szteroidális ösztrogének (E1, E2, E3) rövid felezési idejủek. Mivel hidrofóbok, ezért koncentrációjuk csökken a vizes fázisokban és felezési idejük 2-6 nap vizes és üledékes közegben (YING et al., 2002). Az E2 és EE2 aerob körülmények között 2-81 nap alatt bomlik le, míg anaerob körülmények között egyik sem bomlik. Ez azt jelenti, hogy az oxidatív állapot befolyásolja a degradáció sebességét (YING et al., 2003). Egy másik tanulmány szerint aerob talajban az E2 15 napon belül lebomlik, és a felezési ideje 3-4,5 nap, anaerob talajban a lebomlás viszont nagyon lassú, felezési ideje 24 nap körüli (YING és KoOKANA, 2005). A környezetben jelenlévö bizonyos baktériumok (Rhodococcus zopfii és Rhodococcus equi szennyvíziszapban) képesek teljes mértékben lebontani a természetes ösztrogéneket (E1 és E2) akár 24 órán belül is (HAMID és EsKICIOGLU, 2012; KHANAL et al., 2006).

Számos más tényező is befolyásolhatja az ösztrogének felezési idejét, mint például a hidrofób részecskék, kovalens kötések, ligandumcsere és migráció a talajrészecskék mikrorendszerein. Az E2 és EE2 hajlamosak fotokatalízis és fotolízis által bomlani, vízi környezetben (PETRIE et al., 2013, WRITER et al., 2011).

Az EE2 lebomlását az USA-ban tanulmányozták. Aerob körülmények között a felezési időt 108 napra becsülték. Megfigyelték, hogy természetes napfényben az EE2 felezési ideje jóval rövidebb lett (ZUO et al., 2013), és megállapították, hogy a szintetikus ösztrogének sokkal perzisztensebbek, mint a természetes ösztrogének.

Az E1, az E2 és az E3 képes egymásba átalakulni. Egyes mikrobák (például nitrifikáló baktériumok) képesek E1-et E3-á alakítani és a szintetikus EE2 átalakítható E1-é a Sphingobacterium sp. jelenlétében, melyet a 2. ábrával 
szemléltetünk (HAIYAN et al., 2007). Tóvizek üledékében, anaerob körülmények között az E2 metanogén, szulfát-, vas- és nitrát- redukáló körülmények között E1-re alakult át, viszont az EE2 nem bomlik le (CZAJKA és LONDRY, 2006). Számos tanulmány szerint az E1 az E2 fö biodegradációs közti terméke. XUAN et al., (2008) tanulmánya alátámasztja, hogy iszapos talajban, abiotikus körülmények között az E2 biodegradáció egyik közti terméke az E1 volt (XUAN et al., 2008). Öntözés esetén a $17 \alpha \mathrm{E} 2$ koncentráció csökkenését, az E1 és a $17 \beta E 2$ ekvivalens növekedését figyelték meg, mely a mikrobiális enzimek katalizálására enged következtetni (MANSELL et al., 2011). A talajban a 17ßE2-bomlás üteme folyamatosan növekszik, ahogy a talajnedvesség megnövekszik, így száraz körülmények között az ösztrogének magasabb koncentrációban is fennmaradhatnak (MANSELL et al., 2011; XUAN et al., 2008).

\section{2. ábra}

Ösztrogének transzformációja aerob mikrooganizmusok jelenlétében (Forrás: ADEEL et al.. 2017)

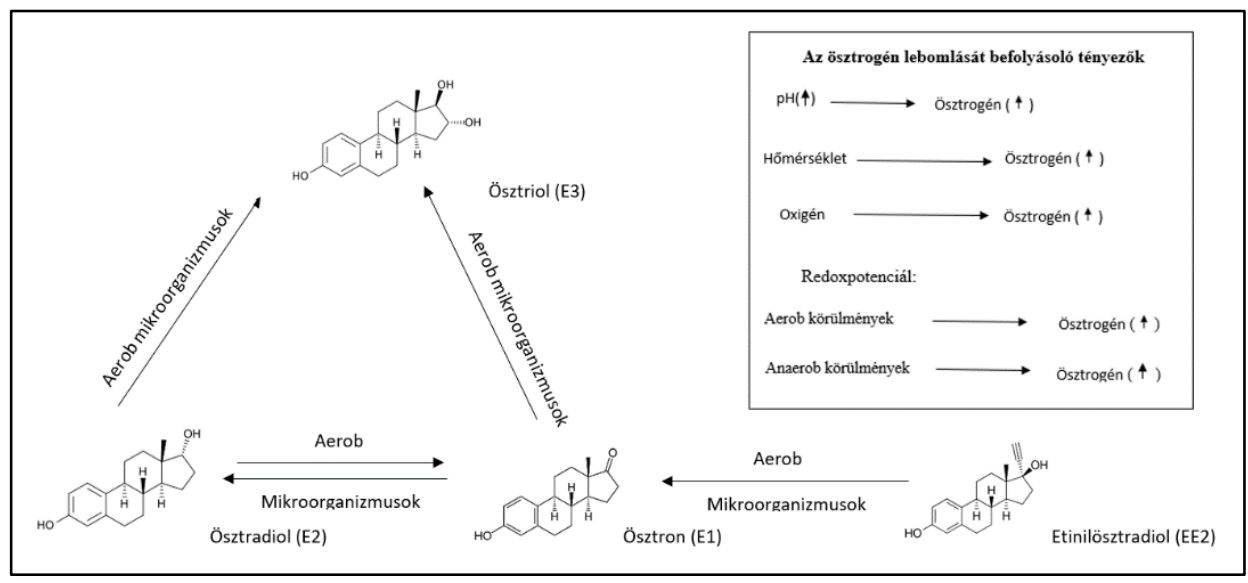

Olyan vízi környezetekben, melyek befogadják a szennyvíztisztítás után visszamaradt megtisztított szennyvizet, több jelenséget is megfigyeltek, melyek az ösztrogének negatív hatásaira utalnak. Több tanulmány is kimutatta, hogy a természetes és mesterséges ösztrogének emelkedett koncentrációja feminizálja a hímivarú halakat (RoSE et al., 2013), és indukálják a vitellogenin (VTG) termelését (KIDD et al., 2007), miközben megváltoznak a reproduktív tulajdonságok (VAN DONK et al., 2016). A vitellogenin a vitellin nevü fehérjének a prekurzora, mely a halak, kétéltűek és tojásrakó állatok kezdeti egyedfejlődési szakaszában játszik fontos szerepet. A vitellogenin gén müködését több hormon szabályozza, legerősebb a petefészek sejtjeiben termelődő $17 \beta-E 2$, ezért a vitellogenin nagyon jó biomarker az ösztrogénhatású anyagok kimutatására (HANSEN et al., 1998; TYLER et al., 1999) 
Az ösztrogén hormonok létfontosságúak az emberi biológia és a fiziológia szempontjából. Segítenek a reprodukció, a szív- és érrendszeri funkciók, a csontszilárdság, a kognitív viselkedés, a sikeres terhesség és a gasztrointesztinális rendszerek szabályozásában (PlOTAN et al., 2014). Az ösztrogének elengedhetetlenek a normál humán fiziológiához, de komoly káros hatással lehetnek, ha a környezetben felhalmozódnak és belépnek az emberi táplálékláncba. Ha a biztonságos küszöbérték felett jutnak az emberi szervezetbe, növelhetik a rák kockázatát és szív- és érrendszeri megbetegedéseket indukálhatnak (WOCŁAWEKРотосKA et al., 2013). A humán mellrákból származó sejtvonalon (pl. MCF-7) végzett tesztekből kiderül, hogy az ösztrogének szupraoptimális szintje összefüggésben lehet a nők emlődaganatának növekedésével (MOORE et al., 1993) és a férfiaknál a prosztatarák kialakulásával (COFFEY, 2001; NELLES et al., 2011), bár az ok-okozati hatás erősen vitatott. Továbbá előidézhetik a korai menopauzát, befolyásolhatják a reproduktív fejlődést és fiatal nőknél is virilizációt okozhatnak. Számos tanulmány kimutatta, hogy az ösztrogének szerepet játszanak a hímivarsejtek spermaszámainak csökkenésében és a férfiak feminizációjában (BOLONG et al., 2009, SUMPTER és JOBLING, 2013).

\section{A növények ösztrogén felvétele}

Jól ismert, hogy bizonyos növények képesek környezetükből a szennyező anyagokat felvenni anélkül, hogy bármilyen negatív hatással lenne a fejlődésükre. Ezt a mechanizmust fitoextrakciónak nevezzük. Számos növényfajt ismerünk, melyek alkalmazkodtak a nehézfémekhez, de sajnos kevés információnk van olyan növényekről, melyek ösztrogén felhalmozásra képesek (MUHAMMAD et al. 2017).

A szennyvízzel végzett folyamatos áramlási tesztek azt mutatják, hogy az algák és a békalencsék kulcsszerepet játszanak az ösztrogének eltávolításában (SHI et al., 2010). Kukoricával végzett kísérletekböl kiderült, hogy a szintetikus és természetes ösztrogének megjelennek a kukorica gyökerében, de csak a 17ß-E2-t mutatták ki a szárban is. A sandbar füz (Salix exigua) és a lúdfü (Arabidopsis thaliana) szintén képesek ösztrogén felvételre. (FrANKS, 2006). Egy japánban végzett hidroponikus vizsgálatban száz különbözö növényt vizsgáltak ösztrogénhatású anyagok jelenlétében, de csak a kövér porcsin (Portulaca oleracea) volt az egyetlen hatékony fitoremediátor. Eltávolította a fenolcsoportot tartalmazó EDC-ket, beleértve a 17ß E2-t 24 órán belül (IMAI et al., 2007).

\section{Az ösztrogének hatása a növények fejlödésére}

Számos tanulmány vizsgálta az exogén szteroid hormonok hatását a csírázásra és a növények fejlődésére. A burgonya gyökérnövekedését és gumónagyságát az ösztrogén (17ß-E2) csökkentette, (BROWN, 2006) míg a kukorica palánták növekedését $10 \mathrm{mg} \mathrm{l}^{-1}$ koncentráció gátolta, de $0,1 \mathrm{mg} \mathrm{l}^{-1}$ stimulálta (BOWLIN, 2014). A mungóbabban és csicseriborsóban E1 és E2 alacsony $(0,1 \mu \mathrm{M})$ koncentrációban fokozott csírázást és vegetatív növekedést mutatott, de nagy $(60 \mu \mathrm{M})$ koncentrációban gátolta a fejlődést (GUAN és RoDDICK, 1988). Lencse esetében a 17ß-E2 kezelés fokozott növekedést és jobb csírázási toleranciát eredményezett a kadmium és a réz stressz szempontjából (CHAOUI és EL FERJANI, 
2013). A Lúdfü (Arabidopsis thaliana) esetében azonban az E1, 17ß-E2 és E3 természetes ösztrogének $(0,1 \mu \mathrm{M})$ koncentrációban csökkentették a generatív növények számát (JANECZKO et al., 2003).

Megemlítendő, hogy a xenoösztrogének képesek interferálni azon fitoösztrogénekkel is, melyek szabályozzák a hüvelyes növények és azok gyökérgümöiben a növénnyel szimbiózisban élő nitrogéngyüjtő Rhizobium baktériumok közti jelátvitelt (FOX , 2004).

\section{Összefoglalás}

Egy vegyület akkor tekinthető ösztrogén hatásúnak, ha alacsony affinitással is, de az ösztrogén receptorokhoz (ER) kötödni képes, az ösztrogén érzékeny sejtekben, szövetekben biológiai hatást képes kiváltani, melyek hasonlóak a petefészek eredetü ösztrogén hormonok által elöidézett folyamatokhoz.

Irodalmi adatok alapján a hígtrágyával történő öntözés és intenzív állattartásból származó trágya termőföldre juttatása következtében a szteroid ösztrogének, beleértve az ösztron E1, ösztradiol E2, ösztriol E3, valamint a szintetikus ösztrogén EE2, mindenütt jelen vannak a termötalajban. A növények felhalmozhatják az ösztrogéneket gyökereikben és hajtásaikban, bekerülve a táplálékláncba akár hatást fejthetnek ki a humán egészségre. A vegyületek ösztrogén potenciálját legtöbbször a 17ß-ösztradiol referencia vegyülethez viszonyított relatív potenciálként fejezik ki. Meghatározó szerepe van a vegyületek minőségének, ugyanis az egyes ösztrogénhatású vegyületek különböző hatással lehetnek a receptorokra

Ahogy korábban említettük, hígtrágya csak talajtani szakvéleményre alapozott talajvédelmi hatósági engedély birtokában juttatható ki mezőgazdasági területre, melyben az is meghatározásra kerül, hogy a területre milyen mennyiségü hígtrágya helyezhető el. A különböző típusú hígtrágyák nemcsak tápanyag összetételben, hanem EDC tartalomban is különböznek egymástól. A természetes hormon kiválasztódás és a hormonhatású készítmények felhasználása tekintetében fontos az állatállomány ivararányát és korcsoportját figyelembe venni. A jövőre nézve fontos, hogy toxikológiai vizsgálatokat végezzünk, és nagyobb hangsúlyt fektessünk a mezögazdasági melléktermékek által kijuttatott hormonhatású anyagok mennyiségére és lehetséges hatásaira.

Kulcsszavak: ösztrogén, EDC, hormonhatás, hígtrágya

\section{Köszönetnyilvánítás}

A publikáció az Innovációs és Technológiai Minisztérium ÚNKP-19-3-I-SZE-3 kódszámú Új Nemzeti Kiválóság Programjának szakmai támogatásával készült. 


\section{Irodalom}

AdeEl, M., Song, X., WANG, Y., Francis, D., YAng, Y. 2017. Environmental impact of estrogens on human, animal and plant life: A critical review. Environment International. 99. 107-119.

Adlercreutz, H., MAZUR, W. 1997. Phyto-oestrogens and Western diseases. Annals of Medicine. 29. 95-120.

Ambra, R., Rimbach, G., De Pascual, T. S., Fuchs, D., WenZel, U., DANIEL, H., VIRGILI, F. 2006. Genistein affects the expression of genes involved in blood pressure regulation and angiogenesis in primary human endothelial cells. Nutrition, Metabolism \& Cardiovascular Diseases. 16. 35-43.

Ankley, G.T., Johnson, R.D., Toth, G., Folmar, L.C., DetenBeCK, N.E., BRADBURY, S.P. 1997. Development of a research strategy for assessing the ecological risk of endocrine disruptors. Rev. Toxicol. Ser. B: Environmental Toxicology. 1. 231-267.

Bolong, N., Ismail, A., SAlim, M.R., Matsuura, T. 2009. A review of the effects of emerging contaminants in wastewater and options for their removal. Desalination. 239. 229-246.

BowLIN, K.M., 2014. Effects of $\beta$-estradiol on Germination and Growth in Zea mays L. M.Sc. thesis. Northwest Missouri State University, Maryville, Missouri, U.S.A.

Buck, G.M., Sever, L.E., MendolA, P., Zielezny, M., VenA, J.E., 1997. Consumption of contaminated sport fish from Lake Ontario and time-topregnancy. New York State Angler Cohort. American Journal of Epidemiology, 146. 949-954.

Byrne, C., DiveKar, S. D., Storchan, G. B., Parodi, D. A. \& Martin, M. B. 2009. Cadmium - a metallohormone?, Toxicology \& Applied Pharmacology. 238. (3) 266-271.

BROWN, G.S. 2006. The Effects of Estrogen on the Growth and Tuberization of Potato Plants (Solanum tuberosum cv. 'Iwa') Grown in Liquid Tissue Culture Media. M.Sc. Thesis. University of Canterbury, New Zealand.

CHAOUI, A., El FERJANi, E. 2013. $\beta$-estradiol protects embryo growth from heavymetal toxicity in germinating lentil seeds. Journal of Plant Growth Regulation. 32. 636-645.

CZAJKA, C. P. \& LONDRY, K. L. 2006. Anaerobic biotransformation of estrogens, Science of the Total Environment. 367. (2-3). 932-941.

COFFEY, D.S. 2001. Similarities of prostate and breast cancer: Evolution, diet, and estrogens. Urology. 57. 31-38.

CsÁvÁs, I., FeKete, L., KISS, O., Vermes, L. 1975. A hígtrágya kezelési módszereinek vizsgálata szakosított sertéstelepeken. Akadémiai Kiadó, Budapest. 103.

DudutZ, GY., KInCSES-AJTAY, M., CsÉP, K. 2009. Fontosabb endokrin diszruptor vegyületek és az élő szervezetekre kifejtett hatásaik. Orvostudományi Értesítő. 82. (3) 156-164.

FISHER, B.E. 1999. Most unwanted. Environ Health Perspect. 107. 18-23. 
FrANKS, C.G., 2006. Phytoremediation of Pharmaceuticals With Salix exigua. M.Sc. Thesis Lethbridge, Alta. University of Lethbridge, Faculty of Arts and Science, Canada.

Fox, J.E. 2004. Chemical Communication Threatened by Endocrine- Disrupting Chemicals. Environmental Health Prespectives.112.648-653.

Gagnon, M.M., Bussieres, D., Dodson J.J., Hodson P.V. 1995. White sucker (Catostomus commersoni) growth and sexual maturation in pulp millcontaminated and reference rivers. Environmental Toxicology \& Chemistry. 14. 317-327.

GuAN, M., RoDDICK, J.G. 1988. Comparison of the effects of epibrassinolide and steroidal estrogens on adventitious root growth and early shoot development in mung bean cuttings. Physiologia Plantarum. 73. 426-431.

Guisti, M., IwAMOTO, K., HATCH, E.E. 1995, Diethylstilbestrol revisited: a review of the longterm health effects. Annals of Internal Medicine. 122. 778-788.

Gomez, E., Pillon, A., Fenet, H., Rosain, D., Duchesne, M.J.,Nocolas, J.C., Balaguer, P., CASellas, C. 2005. Estrogenic activity of cosmetic components in reporter cell lines: parabens, UV screens, and musks. Journal of Toxicology \& Environmental Health. 68. 239-251.

Hansen, P., Dizer, H., Hock, B., Marx, A., Sherry, J., Mcmaster, M., Blaise, C. 1998. Vitellogenin - a biomarker for endocrine disruptors. TrAC Trend in Analytical Chemistry. 17. 448-451.

Hanselman, T. A., Graetz, D. A. \& Wilkie, A. C. 2003. Manure-borne estrogens as potential environmental contaminants: a review, Environmental Science \& Technology. 37. (24) 5471-5478.

Hotchiss, A.K., Rider, C.V., Blystone, C.R., Wilson, V.S., Hartig, P.C., Ankley, G.T., Foster, P.M., Gray, C.L., GrAY, L.E. 2008. Fifteen years after "wingspread"-environmental endocrine disrupters and human and wildlife health: where we are today and where we need to go. Toxicological Sciences 105. 235-259.

Hutchins, S.R., White, M.V., Hudson, F.M., Fine,D,D.2007. Analysis of lagoon samples from different concentrated animal feeding operations for estrogens and estrogen conjugates. Environmental Science and Technology. 41. 738-744.

Hwang, J., SEvanian, A., Hodis, H.N., URSINI, F. 2000. Synergistic inhibition of LDL oxidation by phytoestrogens and ascorbic acid. Free Radical Biology \& Medicine. 29. 79-89.

Imai, S., Shiraishi, A., Gamo, K., Watanabe, I., OKuhata, H., Miyasaka, H., IKEDA, K., BAmBA, T., HiRATA, K. 2007. Removal of phenolic endocrine disruptors by Portulaca oleracea. Journal of Bioscience \& Bioengineering. 103. 420-426.

Ise, R., Han, D., Takahashi, Y., Terasaka, S., InOUe, A., TAnj, M., Kiyama, R. 2005. Expression profiling of the estrogen responsive genes in response to phytoestrogens using a customized DNA microarray. FEBS Letters. 579. 1732-1740. 
JaneczKo, A., FileK, W., Biesaga-Koscielnak, J., MarcinsKa, I., JaneczKo, Z. 2003. The influence of animal sex hormones on the induction of flowering in Arabidopsis thaliana: comparison with the effect of 24-epibrassinolide. Plant Cell, Tissue \& Organ Culture. 72. 147-151.

Johnson, A.C., Williams, R.J, Matthiessen, P. 2006. The potential steroid hormone contribution of farms animals to freshwaters the united kingdom as a case study. Science of Total Environment. 362. 166-178.

Haiyan, R., Shulan, J., Ud Din Ahmed, N., DaO, W., Chengwu, C. 2007. Degradation characteristics and metabolic pathway of $17 \alpha$-ethynylestradiol by Sphingobacterium sp. JCR5. Chemosphere. 66. 340-346.

HAMID, H., ESKICIOGLU, C. 2012. Fate of estrogenic hormones in wastewater and sludge treatment: a review of properties and analytical detection techniques in sludge matrix. Water Research. 46. 5813-5833.

WeI. H., L.YAn-XIA., Y.Ming. 2011. Presence and Determination of Manureborne Estrogens from Dairy and Beef Cattle Feeding Operations in Northeast China. Bull. Environmental Contamination \& Toxicology. 86. 465-469.

Kavlock, R.J., Daston, G.P., De Rosa, C., Fenner-CrisP, P., Gray, L.E., JR., KaAttari, S., Lucier, G., Luster, M., Mac, M.J., MaczKa, C., Miller, R., Moore, J., Rolland, R., Scott, G., Sheehan, D.M., Sinks, T., Tilson, H.A. 1996. Research needs for the assessment of health and environmental effects of endocrine disruptors: a report of the U.S. EPA-sponsored workshop. Environental Health Perspectives. 104. (Suppl 4) 715-740.

KÁDÁR, I. 1995. A talaj-növény-állat-ember tápláléklánc szennyeződése kémiai elemekkel Magyarországon. KTM, MTA-TAKI. Akaprint. Budapest.

Khanal, S.K., XIE, B., Thompson, M.L., Sung, S., Ong, S.K., VAn, L.J. 2006. Fate transport and biodegradation of natural estrogens in the environment and engineered systems. Environental Science \& Technology. 40. 6537-6546.

Kidd, K. A., Blanchfield, P. J., Mills, K. H., Palace, V. P., Evans, R. E., LAZORCHAK, J. M. \& FLICK, R. W. 2007. Collapse of a fish population after exposure to a synthetic estrogen, Proceedings of the National Academy of Sciences of the United States of America. 104. (21) 8897-8901.

MANACH, C., DonOVAn, J.L. 2004. Pharmacokinetics and metabolism of dietary flavonoids in humans. Free Radical Research. 38. 771-785.

Mansell, D.S., Bryson, R.J., Harter, T., Webster, J.P., Kolodziej, E.P., SEDLAK, D.L. 2011. Fate of endogenous steroid hormones in steer feedlots under simulated rainfall-induced run off. Environmental Science Technology. 45. 8811-8818.

MAZur, W.M., Adlercreutz, H. 1998. Naturally occurring estrogens in food. Pure \&Applied Chemistry. 70. 1759-1776.

McMaster Me., VAn Der KraAK, G.J., Portt, C.B., Munkittrick, K.R., Sibley, P.K., SMITH, I.R., DiXON, D.G. 1991. Changes in hepatic mixedfunction oxidase (MFO) activity, plasma steriod levels and age of maturity of a white sucker (Catostomas commersoni) population exposed to bleached kraft mill effluent. Aquatic Toxicology. 21. 199-218. 
Moore, M., Narasimhan, T.R., Steinberg, M.A., Wang, X., Safe, S. 1993. Potentiation of CYP1A1 gene expression in MCF-7 human breast cancer cells cotreted with 2,3,7,8- Tetrachlorodibenzo-p-dioxin and 12-O-Tetradecanolylphorbol-13-Acetate. Archives of Biochemistry \& Biophysics. 305. 483-488.

Muhammad, A., Xiaoming, S., Yuanyuan, W., Dennis, F., Yuesno, Y. 2017. Environmental impact of estrogens on human, animal and plant life. A critical review. Environment International. 99. 107-119.

NACIFF, J.M., JumP, M.L., TORONTAli, S.M., CARR, G.J., Tiesman, J.P., Overmann, G.J., DASTON, G.P. 2002. Gene expression profile induced by 17alpha-ethynyl estradiol, bisphenol A, and genistein in the developing female reproductive system of the rat. Toxicological Sciences 68. 184-199.

Nelles, J.L., HU, W.Y., Prins, G.S. 2011. Estrogen action and prostate cancer. Expert Review of Endocrinology \& Metabolism. 6. 437-451.

NimROD, A.C., BENSON, W.H., 1996. Environmental estrogenic effects of alkylphenol ethoxylates. Critical Reviews in Toxicology. 26. 335-364.

PETERSON, G. 1995. Evaluation of the biochemical targets of genistein in tumor cells. Journal of Nutrition. 125. 784-789.

Petrie, B., MC AdAm, E.J., Scrimshaw, M.D., Lester, J.N., CARTMEll, E. 2013. Fate of drugs during wastewater treatment. TrAC Trends in Analytical. Chemistry. 49. 145-159.

Plotan, M., Elliott, C.T., Frizzel, C., Connolly, L. 2014. Estrogenic endocrine disruptors present in sports supplements. A risk assessment for human health. Food Chemistry. 159. 157-165.

RAMOS, S. 2007. Effects of dietary flavonoids on apoptotic pathways related to cancer chemoprevention. Journal of Nutritional Biochemistry. 18. 427-442.

REINLI, K., BLOCK, G. 1996. Phytoestrogen content of foods - a compendium of literature values. Nutrition \& Cancer. 26. 123-148.

RAPPE, C. 1994. Dioxin, patterns and source identification. Fresenius Journal of Analytical Chemistry. 348. 63-75.

Rose, J., Holbech, H., Lindholst, C., Nrrum, U., Povlsen, A., KorsgaAd, B., BJERREGAARD, P. 2002. Vitellogenin induction by $17 \mathrm{~b}$-estradiol and 17a-ethinylestradiol in male zebrafish (Danio rerio). Comparative Biochemistry \& Physiology Part C: Toxicology and Pharmacology. 131. 531-539.

SCHECTER, A., Olson, J.R. 1997. Cancer risk assessment using blood dioxin levels and daily dietary TEQ intake in general populations of industrial and nonindustrial countries. Chemosphere. 34. 1569-1577.

SHEKHAR, P.V., WERDELl, J., BASRUR, V.S. 1997. Environmental estrogen stimulation of growth and estrogen receptor function in preneoplastic and cancerous human breast cell lines. Journal of the National Cancer Institute. 89. 1774-1782.

ShI, W., WANG, L., Rousseau, D.P., LeNS, P.N. 2010. Removal of estrone, 17 $\alpha-$ ethinylestradiol, and 17ß-estradiol in algae and duckweed-based wastewater treatment systems. Environmental Science Pollution Research. 17. 824-833. 
Shrestha, S.L., Casey, F.X., HakK, H., Smith, D.J., Padmanabhan, G. 2012. Fate and transformation of an estrogen conjugate and its metabolites in agricultural soils. Environmental Science \&Technology. 46. 11047-11053.

SIMON L. (szerk.). 1999. Talajszennyeződés, talajtisztítás. Környezetügyi Müszaki Gazdasági Tájékoztató, 5. kötet. Környezetgazdálkodási Intézet. Budapest.

Siow, R.C., LI, F.Y., Rowlands, D.J., De Winter, P., Mann, G.E. 2007. Cardiovascular targets for estrogens and phytoestrogens: Transcriptional regulation of nitric oxide synthase and antioxidant defense genes. Free Radical Biology \& Medicine. 42. 909-925.

SOHÁR, P.-NÉ., MATYOSOVSZKY, K., PÁLDY, A., VASKÖVI, B.-NÉ. 2003. A POP-ok környezet-egészségügyi jelentősége, élelmiszerekben mérhető szintjeik és egészségügyi kockázatuk (Összefoglaló). Fodor József Országos Közegészségügyi Központ (FJOKK).

SUMPTER, J.P., JOBLING, S. 1993. Detergent components in sewage effluent are weakly estrogenic to fish: an in vitro study using rainbow trout (Oncorhynchus mykiss) hepatocytes. Aquatic Toxicology. 27. 661-672.

Stefanovits, P. 1992. Talajtan, Mezőgazdasági Kiadó, Harmadik kiadás. Budapest.

Tyler, C.R., VAn Aerle, R., Hutchinson, T.H., MaddiX, S., TRIP, H. 1999. An in vivo testing system for endocrine disruption in fish early life stagesusing induction of vitellogenin. Environmental Toxicology \& Chemistry. 18. 337-347.

VAn Der Linden, S. C., Heringa, M. B., Man, H. Y., SONNEVeld, E., PuiJKer, L. M., BRouwER, A. \& VAN DER BURG, B. 2008. Detection of multiple hormonal activities in wastewater effluents and surface water, using a panel of steroid receptor CALUX bioassays, Environmental Science \& Technology. 42. (15) 5814-5820.

Van Donk, E., Peacor, S., Grosser, K., Domis, L.N.D.S., LÜrling, M. 2016. Pharmaceuticals may disrupt natural chemical information flows and species interactions in aquatic systems: ideas and perspectives on a hidden global change. In: DE VOOGT, P. (Ed.), Reviews of Environmental Contamination \& Toxicology. Springer, Heildeberg, Germany. pp. 91-105.

VERMES, L. 1995. A talajszennyezettség megelőzésének, illetve felszámolásának jelentősége és lehetőségei. Agrokémia és Talajtan. 44. 293-298.

VERMES, L. 2005. Hulladékgazdálkodás, hulladékhasznosítás. Mezőgazda Kiadó. Budapest.

Watanabe, S., Yamagzchi, M., Sobue, T., Takahashi, T., Miura, T., Arai, Y., MAZUR, W., WÄHÄLÄ, K., ADLERCREUTZ, H. 1998. Pharmacokinetics of soybean isoflavones in plasma, urine and feces of men after ingestion of $60 \mathrm{~g}$ baked soybean powder (kinako). The Journal of Nutrition. 128. 1710-1715.

Weisglas-KuPerus,N., Patandin, S., Berbers, G.A., Sas, TC., Mulder, P.G., SAUER, P.J., HOOIJKAAS, H. 2000. Immunologic effects of background exposure to polychlorinated biphenyls and dioxins in Dutch Preschool children. Environmental Health Perspectives. 108.1203-1207. 
WocŁaweK-Potocka, I., Mannelli, C., BorusewszKa, D., KowalczyK-Zieba, I., WASNIEVSKI, T.,SKARZINSKY, D.J. 2013. Diverse effects of phytoestrogens on the reproductive performance: cow as a model. International Journal of Endocrinology. ID:650984. 1-15. http://dx.doi.org/10.1155/2013/650984.

Writer, J.H., RYAN, J.N., KEEFE, S.H., BARBER, L.B. 2011. Fate of 4-nonylphenol and $17 \beta$-estradiol in the Redwood River of Minnesota. Environmental Science \& Technology. 46. 860-868.

YING, G. G. \& KoOKANA, R. S. 2005. Sorption and degradation of estrogen-likeendocrine disrupting chemicals in soil, Environmental Toxicology \& Chemistry. 24. (10) 2640-2645.

YING, G.G., KoOKANA, R. S., RU YING-JUN. 2002. Occurrence and fate of hormone steroids in the environment. Environment International. 28. 545-551.

YING, G.G., KoOKANA, R.S., DiLlON, P. 2003. Sorption and degradation of selected five endocrine disrupting chemicals in aquifer material. Water Research. 37. 3785-3791.

ZHENG, W., YATES, S.R., BRADFORD, S.A. 2008. Analysis of steroid hormones in a typical dairy waste disposal system. Environmental Science \& Technology. 42. 530-535.

ZuO, Y., ZHANG, K., ZHOU, S., 2013. Determination of estrogenic steroids and microbial and photochemical degradation of $17 \alpha$-ethinylestradiol (EE2) in lake surface water, acase study. Environmental Science: Processes \& Impacts. 15.1529-1535.

Xuan, R., Blassengale, A.A., WAng, Q. 2008. Degradation of estrogenic hormones in a siltloam soil. J. Agricultural Food Chemistry. 56. 9152-9158.

\title{
Oestrogens and oestrogenic substances in plant cultivation
}

\author{
${ }^{1}$ Eduard GubÓ, ${ }^{1}$ Pál SzAKÁL, ${ }^{1,2}$ Judit Plutzer \\ ${ }^{1}$ Széchenyi István University, Faculty of Agricultural and Food Sciences, \\ ${ }^{2}$ National Public Health Center, Budapest
}

\section{Summary}

A compound is oestrogenic, when -even if with low affinity but can bind to oestrogen receptors (ER)- resulting in a biological effect in oestrogen sensitive cells, which are similar to processes caused by the ovarian derived oestrogen hormones. According to literature data, due to slurry irrigation and intensive livestock manure application, due to the direct contact with the land, steroidal oestrogens, including oestrogen E1, oestradiol E2, oestriol E3, and synthetic oestrogen EE2 are ubiquitous in the fertile soil. Plants can accumulate oestrogens in their roots and shoots, which when entering the food chain may have an impact on human health. Slurry can only be applied to agricultural land with the permission of the soil protection authority, which also determines the amount of slurry that can 
be applied to the area. The different types of slurry differ not only in their nutrient composition but also in their EDC content. Regarding the natural hormone excretion and use of hormonal preparations it is important to consider the sex ratio and age range of livestock in the case of selection.

It is important for the future that we carry out toxicological studies and place greater emphasis on the amount and potential effects of hormonal substances released by agricultural side products.

Keywords: oestrogen, EDC, hormone effects, slurry

\section{Tables and figures}

Figure 1 Chemical structure of natural and synthetic oestrogens

Figure 2 Transformation of oestrogens in the presence of aerobic microorganisms

Open Access nyilatkozat: A cikk a Creative Commons Attribution 4.0 International License (https://creativecommons.org/licenses/by/4.0) feltételei szerint publikált Open Access közlemény, melynek szellemében a cikk bármilyen médiumban szabadon felhasználható, megosztható és újraközölhető, feltéve, hogy az eredeti szerző és a közlés helye, illetve a CC License linkje és az esetlegesen végrehajtott módosítások feltüntetésre kerülnek. (SID_1) 